\title{
The Analysis of the Causes in Changes of Japan's ODA Policies to China
}

\author{
Chen Lu',2, Weiwei Fan' \\ ${ }^{1}$ Huazhong University of Science and Technology, Wuhan, China \\ ${ }^{2}$ Wuhan University of Science and Technology, Wuhan, China \\ Email: luchen@wust.edu.cn, fanweiwei@hust.edu.cn
}

Received 9 April 2014; revised 13 May 2014; accepted 23 June 2014

Copyright (C) 2014 by authors and OALib.

This work is licensed under the Creative Commons Attribution International License (CC BY).

http://creativecommons.org/licenses/by/4.0/

c) (i) Open Access

\begin{abstract}
This paper discusses recent issues related to the changes in the relationship between Japan and China, mainly focuses on the alterations in Japan's ODA towards China during 30 years and its reasons from economic and political perspectives. The changes can be divided into three main periods. The first period was in the 1980 s to mitigate the pressure of Sino-Japanese relationship and regain Japanese economic vitality in postwar; the second was in the 1990s, Japan shifted its ODA policy from "development aid" to "strategic aid" after the Cold War, and the third was in the beginning of the $21^{\text {st }}$ century, Japan reduced the Yen loans sharply to China (Shen 2007). The paper will start researching the question from those points, namely what are the related backgrounds of ODA policies in those three periods, and the causes of the changes, and in the end the article draws a conclusion of the benefits from ODA to both Japan and China, and the implication of this case.
\end{abstract}

\section{Keywords}

ODA, Japan, China, Political Relationship

Subject Areas: Economics, International Relations, Politics

\section{Introduction}

The official development assistance (ODA) is a large-scale economic assistance to developing countries with grant aid or loan aid from the official departments or agencies of developed countries, inclusive of over 25\% grant element (using a fixed 10\% rate of discount), compiled by the Development Assistance Committee (DAC) of the Organisation for Economic Cooperation and Development (OECD) [1]. It aims to help the developing countries with supplies, civil engineering and other assistance, promoting their economic development and welfare for people's living conditions [2]. In terms of Japan's ODA, Japan started to provide assistance by joining 
the Colombo Plan in 1954, being one of the largest donors from 1991, and supporting 185 countries and regions, providing over \$271.4 billion till 2008 for developing countries, accounted for 1/4 or more in total net ODA from OECD members (See Table 1) [3]. More specifically, since 1979, Japan's ODA towards China had played a pivotal role in Chinese economic reform and openness policy along with the development of globalization as well as in the social welfare over the past 30 years, "reducing bottlenecks in the coastal area, improving environmental management, upgrading basic human needs such as public health, and promoting human resources development" [3]. Being the largest donor to China, Japan stood for more than $60 \%$ of all bilateral aid provided to China in all donors [4]. Japan’s ODA to China consisted of three parts, namely Yen loans, grant aid and technical cooperation assistance. China had obtained approximately ¥3.4 trillion Yen loans from 1979 to 2007, being key ingredient in ODA, accounted for 80\% in total ODA from Japan; grant aid of ¥1416 billion Yen in several areas like medical care, environment protection, and education; technical cooperation assistance of ¥1385 billion in sending Japanese technicians to China, and supporting advanced equipment [5].

Since the implementation of Japan's ODA to China, not only has the Chinese economic development and people's living standard been improved, but also the Sino-Japanese relations have been promoted; and that, Japan's ODA became the symbol of Sino-Japanese friendship in postwar [6]. However, along with the development of both countries in the 21st century, Japan has gradually changed its ODA policy to China at different

Table 1. Net ODA from DAC countries from 1991 to 2008.

\begin{tabular}{|c|c|c|c|c|c|c|}
\hline ODA Net USD Million & 1991 & 1992 & 1993 & 1994 & 1995 & 1996 \\
\hline Canada & 2604 & 2515 & 2400 & 2250 & 2067 & 1795 \\
\hline Denmark & 1200 & 1392 & 1340 & 1446 & 1623 & 1772 \\
\hline France & 7386 & 8270 & 7915 & 8466 & 8443 & 7451 \\
\hline Japan & 10,952 & 11,151 & 11,259 & 13,239 & 14,489 & 9439 \\
\hline Norway & 1178 & 1273 & 1014 & 1137 & 1244 & 1311 \\
\hline Sweden & 2116 & 2460 & 1769 & 1819 & 1704 & 1999 \\
\hline United Kingdom & 3201 & 3243 & 2920 & 3197 & 3202 & 3199 \\
\hline United States & 11,262 & 11,709 & 10,123 & 9927 & 7367 & 9377 \\
\hline ODA Net USD Million & 1997 & 1998 & 1999 & 2000 & 2001 & 2002 \\
\hline Canada & 2045 & 1707 & 1706 & 1744 & 1533 & 2004 \\
\hline Denmark & 1637 & 1704 & 1733 & 1664 & 1634 & 1643 \\
\hline France & 6307 & 5742 & 5639 & 4105 & 4198 & 5486 \\
\hline Japan & 9358 & 10,640 & 12,163 & 13,508 & 9847 & 9283 \\
\hline Norway & 1306 & 1321 & 1370 & 1264 & 1346 & 1696 \\
\hline Sweden & 1731 & 1573 & 1630 & 1799 & 1666 & 2012 \\
\hline United Kingdom & 3433 & 3864 & 3426 & 4501 & 4566 & 4929 \\
\hline United States & 6878 & 8786 & 9145 & 9955 & 11,429 & 13,290 \\
\hline ODA Net USD Million & 2003 & 2004 & 2005 & 2006 & 2007 & 2008 \\
\hline Canada & 2031 & 2599 & 3756 & 3683 & 4080 & 4785 \\
\hline Denmark & 1748 & 2037 & 2109 & 2236 & 2562 & 2803 \\
\hline France & 7253 & 8473 & 10,026 & 10,601 & 9884 & 10,908 \\
\hline Japan & 8880 & 8922 & 13,126 & 11,136 & 7679 & 9579 \\
\hline Norway & 2042 & 2199 & 2786 & 2954 & 3728 & 3963 \\
\hline Sweden & 2400 & 2722 & 3362 & 3955 & 4339 & 4732 \\
\hline United Kingdom & 6262 & 7905 & 10,772 & 12,459 & 9849 & 11,500 \\
\hline United States & 16,320 & 19,705 & 27,935 & 23,532 & 21,787 & 26,842 \\
\hline
\end{tabular}

Source: OECD Statistics Portal 2009, www.oecd.org/dac/stats. Note: Including debt forgiveness of non-ODA claims, except for total DAC. 
times for various reasons, and in March 2008, Japan had given 463 billion Yen loans to China for the last time [7]. Those big changes have been in the spotlight in both countries recently. Some assert that Japan's ODA policies to China were totally built on Japan's own interests, focus on stimulating Japanese export to China and taking precaution against the rise of China [8]. While others consider that the changes of policies were inevitable and people should keep a rational mind to those changes, for the policy changing was regarding to the changes in the international and domestic situations and other specific reasons [9]. Therefore, what are the exactly causes of those changes in Japan's ODA to China during 30 years? It should be discussed with looking back to its initial motivation and varying economic and political environment.

\section{The Beginning of Japan's ODA to China in the 1980s and Its Reasons}

After the World War II, Japan had received the emergency aid from America through Government and Relief in Occupied Areas (GARIOA), aiming to help Japan recovering from postwar recession. Then, Japan turned itself from recipient to donor successfully by joining "Colombo Plan" in 1954, starting its ODA diplomacy to Asia. In the 1970s, on the one hand, due to the substantial surplus of Japan's international balance of payments, U.S. and other DAC members required Japan to increase its ODA to other developing countries, for the sake of supporting more developing countries to improve their economic development and social stability. On the other hand, China suffered from lacking of capital for economic and social constructing and doing international trade. (Shi 2009) Thereafter, under the circumstances, China had been one of the recipients of Japan's ODA from 1979 for those reasons below.

Firstly, it was the demand of Japan's diplomacy in pursuing the same political position as its vigoroso economic strength world-wide [10]. The Japanese state regards ODA as a crucial diplomatic instrument to ensure national security by promoting economic development and political stability [11]. Therefore, the Japanese state considered that sustaining a stable relationship with countries surrounding Japan was of great importance in postwar. Japan’s Prime Minister Ohira proposed a “three principles” when he visited China in Dec. 1979, saying that Japan and China cannot do military cooperation, indicated that Japan had no offense to the Soviet during the Cold War; the ODA policy should be without destroying the relations with other Asian countries, especially the Association of Southeast Asian Nations members (ASEAN); in order to eliminate the qualms from DAC members on monopolizing the Chinese emerging market, for Japan was the first donor to China, the ODA policy to China was upon the coordination with other DAC members [10]. It can be seen from the principles that Japan used ODA policy as a means of diplomatic strategy to handle its problems on relations with other countries like Soviet and the third world countries to build a relatively stable environment for its developing in postwar.

Secondly, it was Japan's economic need, taking advantage of ODA as leverage to improve export to China and import diversified energy sources from China. For instance, in China, though there were sources of oil, natural gas and coal in abundance, the backward technique of mining and transportation facilities impeded the exchange trade between Japan and China [5]. Thus, Yen loans can help China to improve their technology and transportation capacity to ensure the sustained and sufficient energy supply to Japan. And some Japanese scholars said that Japan had high expectation on importing energy sources from China in the long-term, and it was a critical reason for Japan's Yen loans to China [5].

Thirdly, it was a kind of reparation to China, for Chinese government had given up war compensation. During the World War II, China suffered a lot from the Japanese invasion. And Japanese Prime Minister Ohira responded that Japanese should keep a rational and fair mind on the unfortunate result of wars between Japan and China, and some Japanese scholars also assert that the action of given up war compensation was an important reason for the decision of Japan's ODA towards China.

During the 1980s, along with the incremental amount of ODA from Japan, (See Table 2) China benefited a lot from both Yen loans and grant aid, such as the government not only utilized the Yen loans to construct the Qinhuangdao Coal Terminal, Beijing capital airport and $4600 \mathrm{~km}$ of China electric railway, but also received the grant aid in building "the Chinese and Japanese Youth Exchange Center" as well as the famous "China-Japan Friendship Hospital". Thus, in the first period, ODA from Japan to China achieved a "win-win" situation in both countries.

\section{The Changes of Japan's ODA after the Cold War and Its Causes}

After the end of the Cold War in 1991, along with the development between Japan and China, the imbalance of 
Table 2. Japan's ODA to China from 1979 to 2000.

\begin{tabular}{cccc}
\hline & \multicolumn{4}{c}{ Japan's ODA to China from 1979 to 2000 } \\
\hline Loan batch & Year & Loan amount (billion Yen) & Projects funded by Japan \\
\hline 1st & $1979-1983$ & 3309 & 6 \\
2nd & $1984-1989$ & 4700 & 16 \\
3rd & $1990-1995$ & 8100 & 42 \\
4th & $1996-2000$ & 9698 & 74 \\
\hline
\end{tabular}

Source: Embassy of the People’s Republic of China in Japan.

the development appeared increasingly evident. Due to rapid development of China, more and more people in Japan started questioning about Japan's ODA to China. For some political reasons, subtle changes took place in Japan's ODA to China, shifting its ODA policy from "development aid" to "strategic aid" after the Cold War with decreasing Yen loans and increasing grant aid.

For one thing, Japan had added some political conditions to ODA to China. In June 1992, the Japanese cabinet made an ODA Charter to its all recipient countries, presenting a "four principles of ODA", indicated that the official assistance should be connected with environmental protection; the Yen loans cannot be used in military; the Japanese state should pay more attention to the areas in military spending, export and import of weapons, and development of weapons of mass destruction and missile of the recipients; and be aware of the democracy and human rights [12]. The announcement of "four principles" indicated that Japan changed to strategic aid, focusing more on the constrained conditions in politics and military in the recipient countries. For example, China did two nuclear tests in both May and Aug. 1995, Japan cut down its grant aid from ¥78 billion Yen in 1994 to merely $¥ 5$ billion Yen in 1995; again, China did its nuclear test in June 1996, and Japan had postponed the $4^{\text {th }}$ batch of Yen loans to China simultaneously [5]. Apparently, Japan was fearful of China probably using Yen loans to develop its military strength, for it might be a threat to Japan's national security and political stability. So during the 1990s, Japan always used ODA to constrain the Chinese military development.

For another, from the aspect of Yen loans, Japan changed from 5 years plan to one year plan to decide the amount of the loans, and the amount of Yen loans decreased year by year [5]. This was mainly because of the "harsh views" and criticisms from the Japanese public, especially the right-wing forces, advocating that the rise of China may be a threat to the Japanese development [13].

Furthermore, there was another "four principles for ODA to China" in Dec. 1991, showing that the aim of the ODA was to maintain the friendship between Japan and China; Japan will absolutely be the backup of Chinese economic reform and openness; the ODA should be focused on the imbalance of development between the coastal area and the inland area in China, aiming to create a healthy and virtuous circle of the economy; and Japan started seeking the proper aiding ways by analyzing the actual situation in China in terms of the scale of population and territory [10]. These principles profoundly manifested in the following ways: increasing projects funded by Japan's ODA in environmental protection, agriculture, and the Midwest region of China [5]. In respect that the energy issues mentioned above in the 1980s had already eased due to the stable international energy market and the sufficient energy store in Japan, so Japan's initial intention of energy importing from China gradually faded away in the 1990s. This is another reason to explain the decreasing Yen loans from Japan to China.

\section{The Readjustment in Japan's ODA in the 21st Century and Its Causes}

In pace with the dramatic changes and development in the international and domestic situation in Japan, the ODA to China experienced a period of adjustment and cooling. In fact, the whole policy of Japan's ODA to its all recipient countries had been changed, more specifically, Japan cut down its total net ODA from \$13,508 million in 2000 to $\$ 9847$ million in 2001, a 27.1\% decline. (See Table 3) For China in 2001, total net ODA from Japan dropped 8.2\% to \$96.4 billion, and in terms of Yen loans, it fell 24.7\% to ¥1613.66 billion Yen (See Table 4).

The main reason for this change is that in Oct. 2003, a New ODA Charter had been proposed by the Japanese government, identifying that with increasing fiscal deficits and debt in recent years, due to the stagnation of the Japanese economy, Japan could never generate the same level of public support for ODA as in the past [11]. 
Table 3. Net ODA in Japan from 1999 to 2008.

\begin{tabular}{cccccc}
\hline ODA Net USD Million & $\mathbf{1 9 9 9}$ & $\mathbf{2 0 0 0}$ & $\mathbf{2 0 0 1}$ & $\mathbf{2 0 0 2}$ & 9283 \\
\hline Japan & 12,163 & 13,508 & 9847 & $\mathbf{2 0 0 3}$ & $\mathbf{2 0 0 6}$ \\
Japan & $\mathbf{2 0 0 4}$ & $\mathbf{2 0 0 5}$ & 11,136 & 7679 & 9579 \\
\hline
\end{tabular}

Source: OECD Statistics Portal 2009, www.oecd.org/dac/stats.

Table 4. Japan's ODA to China from 2001 to 2004.

\begin{tabular}{cccc}
\hline \multicolumn{2}{c}{ Japan's ODA to China from 2001 to 2004 } \\
\hline Year & Loan amount (billion Yen) & Year on year decline rate (\%) & Projects funded by Japan \\
\hline 2001 & 1613.66 & 24.7 & 15 \\
2002 & 1212.14 & 25.0 & 13 \\
2003 & 966.92 & 20.0 & 25 \\
2004 & 858.75 & 11.2 & 8 \\
\hline
\end{tabular}

Source: Embassy of the People’s Republic of China in Japan.

And another reason is that according to a Japanese opinion poll, those who favored "more ODA for developing countries" decreased from $41 \%$ in 1991 to $28 \%$ in 1998; those who favored "less ODA" increased from $8 \%$ to $19 \%$ over the same period [14]. There was an increasing number of Japanese insisting that ODA should not be given to those countries, such as China, with large military spending and weapons of mass destruction [11]. As a result of those criticisms with the current economic facts, a budget cut in ODA had been proposed since 1998, and implemented in 2001.

Moreover, as China has developed and modernized over the past 30 years, becoming a major military power as a third world country, such as the successful first manned flight of Shenzhou V, Japan begun to ponder if current level of ODA is too high for China, in that China is rising and it might be a rival to Japan in the international trade. In March 2005 in Japan, the ODA policymakers in a meeting pointed out that accompanied by the economic rising of China, according to the Chinese National Bureau of Statistics, from 1978 to 1999, China's gross domestic savings increased from 211 billion RMB to 5.96 trillion RMB, and that with those reasons of increasing spending on military development; the incremental amount of China's own economic assistance to other third world countries while receiving aid from Japan, and the Chinese public does not seem to be aware of the size nor significance of Japan's ODA to China, and shows little appreciation for Japanese help, thus the Yen loans seems to have less impact on Chinese economic development than before [10]. The policymakers also insisted on that "China should rely more on domestic savings and foreign private capital to build hard infrastructure, and the domestic intra-governmental fiscal transfer system should be strengthened to address poverty reduction, particularly in the Midwest area" [11]. Additionally, there was no new agreement between Japan and China on the amount of Yen loans in 2008. These facts indicated that the Yen loans to China are coming to an end. In the future, the ODA towards China from Japan will focus more on the mutually concerned issues like the development of environment, climate and energy through grant aid and technical cooperation assistance [10].

In fact, Japan's ODA towards China enables both Japan and China achieving great success in the economic and political development. On the one hand, over the past 30 years, ODA from Japan helped China to build many infrastructures which promoted the development of Chinese economy and society, sped up the modernization and Western development, and improved the living conditions of the local people. On the other hand, Japan also won huge benefits from ODA to China, being one of Chinese largest trade partner for years. In terms of Sino-Japan trade, the total bilateral trade went up to $\$ 2668$ billion, a 13\% rise compared to trade in 2007 and about 250 times higher than $\$ 10.4$ billion in 1972; the Chinese import trade from Japan increased 12.5\% to $\$ 1507$ billion compared to trade in 2007 [15]. Japan received large amount of energy sources importing from China while Japan was suffering from the energy crisis in the 1980s, and Japan had successfully exploited and obtained the emerging market in China during the 30-year period. 


\section{Conclusions}

In sum, this paper examines the causes of the changes in ODA towards China from Japan during 30 years, given the phenomenon of "a rising China and a stagnating Japan" to discuss its influences on the ODA policy decision making. Japan's ODA policies to China were based on the international and domestic economic and political environment. If the environment changed, the policies would be changed in the meantime. As the case shows that, in postwar, in order to improve the Sino-Japan relationship and stimulate import and export trade between Japan and China, Japan started its ODA to China from 1979; after the Cold War, the whole world structure changed into the trend of world multipolarization, and then due to its political reasons, holding a view that the development of Chinese military power might be a threat to Japan's national security and political stability, Japan shifted its ODA policy to China from "development aid" to "strategic aid", specifically addressing that ODA cannot use in military development in China, and focusing more on the development of environmental protection, agriculture and Midwest region in China; in the beginning of the $21^{\text {st }}$ century, because of the rising of China and stagnation of Japan and the criticisms from the public in Japan, the ODA policy changed again to suspend the Yen loans from 2008 to China and only remaining the grant aid and technical cooperation assistance in the development of environment, climate and energy.

This case indicates that the policy making of national state is usually upon the background of international and domestic environment and connected with its own interests in a globalized world. And the policy of international trade becomes a fairly important instrument to balance its relationship and interests with other countries. It does not mean that the state will be hollowed out nor have less power on international trade, actually it means that the state will use its own power to change the policies to influence the economy indirectly. Take Japan's ODA to China for example, according to the changes in the international and domestic environment, Japan shifted its priorities in ODA policy just because its government has the intention to keep a stable relationship with DAC members, ASEAN, and China to create a relatively steady and secure economic and political environment for Japanese development, and then the state used its power to change the policies, and finally influenced the trade and relationship between Japan and China.

In addition, with the rising power of the third world countries like China, the first world countries should keep a rational and fair mind, not constrain or hold back the new rising forces, but help and develop each other in the future in the global business. For instance, Japan as one of the first world countries, gave ODA to China for 30 years long which is a win-win policy, as a result, on the one hand, Japan's ODA accelerated the development of Chinese economy and society; on the other hand, Japan benefited from the rich energy sources and huge emerging market in China.

\section{References}

[1] Wikipedia. Official Development Assistance. http://en.wikipedia.org/wiki/Official_development_assistance

[2] Wikipedia. Official Development Assistance (Japan). http://en.wikipedia.org/wiki/Official_Development_Assistance_(Japan)

[3] Ministry of Foreign Affairs (2004) Japan’s ODA: Accomplishment of 50 Years. http://www.mofa.go.jp/POLICY/oda/cooperation/anniv50/pamphlet/accomplishment1.html

[4] Wu, Z.G. (2008) Research on Japan's ODA to China and Its Contribution to China's Development. Project on the Chinese Economy, ORC, Kyoto Sangyo University, 1-14. http://www.cc.kyoto-su.ac.jp/project/orc/econ-public/china/documents/WUDP28.pdf

[5] Shen, M.H. (2007) Changes in Japan's ODA Policies to China and Their Causes. Journal of Hangzhou Normal University (Social Sciences Edition), 6, 71-75.

[6] Chen, Z.W. and Lin, F.C. (2007) The Political and Economic Analysis of Changes in Japan’s ODA Policy. Market Modernization, 493, 20-21.

[7] Han, A.Y. (2009) Official Development Assistance and Its Political Gains: A Case Study of Japanese ODA for Southeast Asian Nations. Theoretical Horizon, 1, 53-55.

[8] Lei, C.L. (2008) On the Inevitability of Japan’s ODA and China's Strategies. Journal of Wuhan Institute of Technology, 7, 49-53.

[9] Sun, X.Y. and Ma, J.Y. (2007) Analysis of the Change of Japan’s ODA Policy to China. Journal of Northeastern University (Social Science), 9, 139-143.

[10] Shi, Q.B. (2009) The Policy Evolution and the Role of Japan’s ODA to China. History Teaching, 14, 54-59. 
[11] Masahiro, K. and Shinji, T. (2001) Japan’s Official Development Assistance: Recent Issues and Future Directions. Woodrow Wilson International Center for Scholars, 97, 1-24.

[12] Jin, X.D. (2000) The Study of Japan's ODA. 1st Edition, Social Sciences Academic Press.

[13] Masayuki, M. (2003) Japan’s Changing ODA Policy towards China. China Perspectives: Foreign Policy, 47, 40-49.

[14] Katada, S.N. (2001) Why Did Japan Suspend Foreign Aid to China? Japan’s Foreign Aid Decision-Making and Sources of Aid Sanction. Social Science Japan Journal, 4, 39-58. http://dx.doi.org/10.1093/ssij/4.1.39

[15] Caixun (2009) Customs Head Office: Sino-Japan’s Total Bilateral Trade Increased 13\%. http://content.caixun.com/NE/01/65/NE0165sa.shtm 